\title{
The impact of hereditary cancer gene panels on clinical care and lessons learned
}

\author{
Volkan Okur ${ }^{1}$ and Wendy K. Chung ${ }^{1,2}$ \\ ${ }^{1}$ Division of Molecular Genetics, Department of Pediatrics, Columbia University Medical Center, New York, \\ New York 10032, USA; ${ }^{2}$ Department of Medicine, Columbia University Medical Center, New York, New York \\ 10032, USA
}

\begin{abstract}
Mutations in hereditary cancer syndromes account for a modest fraction of all cancers; however, identifying patients with these germline mutations offers tremendous health benefits to both patients and their family members. There are about 60 genes that confer a high lifetime risk of specific cancers, and this information can be used to tailor prevention, surveillance, and treatment. With advances in next-generation sequencing technologies and the elimination of gene patents for evaluating genetic information, we are now able to analyze multiple genes simultaneously, leading to the widespread clinical use of gene panels for germline cancer testing. Over the last 4 years since these panels were introduced, we have learned about the diagnostic yield of testing, the expanded phenotypes of the patients with mutations, and the clinical utility of genetic testing in patients with cancer and/or without cancer but with a family history of cancer. We have also experienced challenges including the large number of variants of unknown significance (VUSs), identification of somatic mutations and need to differentiate these from germline mutations, technical issues with particular genes and mutations, insurance coverage and reimbursement issues, lack of access to data, and lack of clinical management guidelines for newer and, especially, moderate and low-penetrance genes. The lessons learned from cancer genetic testing panels are applicable to other clinical areas as well and highlight the problems to be solved as we advance genomic medicine.
\end{abstract}

Corresponding author:wkc15@ columbia.edu

(C) 2017 Okur and Chung This article is distributed under the terms of the Creative Commons Attribution-NonCommercial

License, which permits reuse and redistribution, except for commercial purposes, provided that the original author and source are credited.

Published by Cold Spring Harbor Laboratory Press

doi: $10.1101 / \mathrm{mcs} . \mathrm{a} 002154$
Cancer is among the leading causes of morbidity and mortality worldwide. Germline mutations for monogenic, highly penetrant cancer susceptibility genes are observed in $5 \%-10 \%$ of all cancers (Lu et al. 2014), and many solid organ cancers have clinical guidelines for evaluation and genetic counseling/testing (Hampel et al. 2015; Robson et al. 2015). Hereditary cancers due to monogenic causes are characterized by earlier age of onset, other associated cancers, and often a family history of specific cancers or associated features. It is clinically important to recognize these individuals and their family members to guide clinical management for those with cancer (Hennessy et al. 2010; Ledermann et al. 2014; Pennington et al. 2014; Kurian et al. 2017) and to identify at-risk patients who will benefit from enhanced surveillance to permit early detection and/or risk reduction measures (Kurian et al. 2010). Identification of carriers of cancer predisposition genes also enables cascade genetic testing of at-risk family members to refine risk and identify both high and average risk family members, tailor care to improve outcomes, and more efficiently use health-care resources. 


\section{THE ROAD TO HEREDITARY CANCER GENE PANELS}

Cancers have long been recognized to run in certain families. Because of the expense to Sanger sequence hereditary cancer genes such as BRCA1/2 or mismatch repair genes in Lynch syndrome, genetic testing guidelines were developed 10-15 years ago for many common cancers to identify patients with a high probability of carrying a cancer predisposition mutation. These guidelines were incorporated into the predictors such as BRCAPro (Parmigiani et al. 1998), Amsterdam (Vasen et al. 1991), and Bethesda (Rodriguez-Bigas et al. 1997) or modified Bethesda criteria (Umar et al. 2004), which have been utilized to identify patients with a prior probability of at least $10 \%$ to carry a heritable cancer mutation. However, these criteria are not sensitive enough to identify all mutation carriers (Berry et al. 2002). For example, although several risk estimate algorithms have been developed and genetic testing for hereditary breast and ovarian cancer (HBOC) has been available for 20 years, it was estimated as of 2012 that only $30 \%$ of patients with breast cancer and $5 \%$ of asymptomatic BRCA1/2 carriers may have been identified in the United States (Drohan et al. 2012).

With the reduction in the cost of sequencing with next-generation sequencing (NGS) technologies and using elimination of patents on BRCA1/2 for diagnostic testing in June 2013 , there was an immediate increase in the number of genes that could be evaluated simultaneously and in the number of laboratories that entered the market. This had the effect of decreasing the price charged from $\$ 3340$ for BRCA1/2 (Myriad Genetics, Annual Report 2012) to now $\$ 250$ for a panel of 30 genes (Color Genomics, 2017), increasing access to testing with more laboratories partnering with more payers, and decreasing turnaround times from 10 wk to $10-21 d$ to enable incorporation of genetic information with medical decision making at the time of initial cancer diagnosis. Coincident with these changes on the laboratory side, in May 2013, Angelina Jolie revealed her BRCA1 status and preventive measures she had undertaken with an op-ed in The New York Times (http://www.nytimes. com/2013/05/14/opinion/my-medical-choice.html). The associated media coverage had a significant impact on increasing the awareness of the public about hereditary cancer (Borzekowski et al. 2014; Kamenova et al. 2014; Kosenko et al. 2016).

\section{EFFECTS ON CANCER GENETICS PRACTICE}

Panel gene testing has doubled the mutation detection rate for patients undergoing either cancer site-specific (Kapoor et al. 2015; Minion et al. 2015) or pan-cancer panels (Ricker et al. 2016; Susswein et al. 2016). As a result, panel testing has increased and become the most common testing option for cancer genetic testing (Blazer et al. 2015).

As laboratories were designing panels of genes to offer in clinical testing, there was and still is incomplete data available on the frequency, penetrance, and cancer spectrum associated with many of the heritable cancer genes, especially for those genes that had been relatively recently identified. Different panel options were constructed and offered by laboratories (Table 1). The majority of the panels included genes for specific hereditary cancer predisposition syndromes and provided various testing options for the number of genes included in the panels ranging from a small number of highly penetrant, well-established genes with NCCN (National Comprehensive Cancer Network) clinical care guidelines to larger panels including more recently identified genes with lower penetrance and/or less certainty about the age-related penetrance and associated cancers (Tables 1 and 2). Laboratories also offered pan-cancer panels covering large numbers of approximately 30 to 60 genes for patients who had family or personal histories that did not fit a single hereditary cancer syndrome. With more expansive testing, it has 


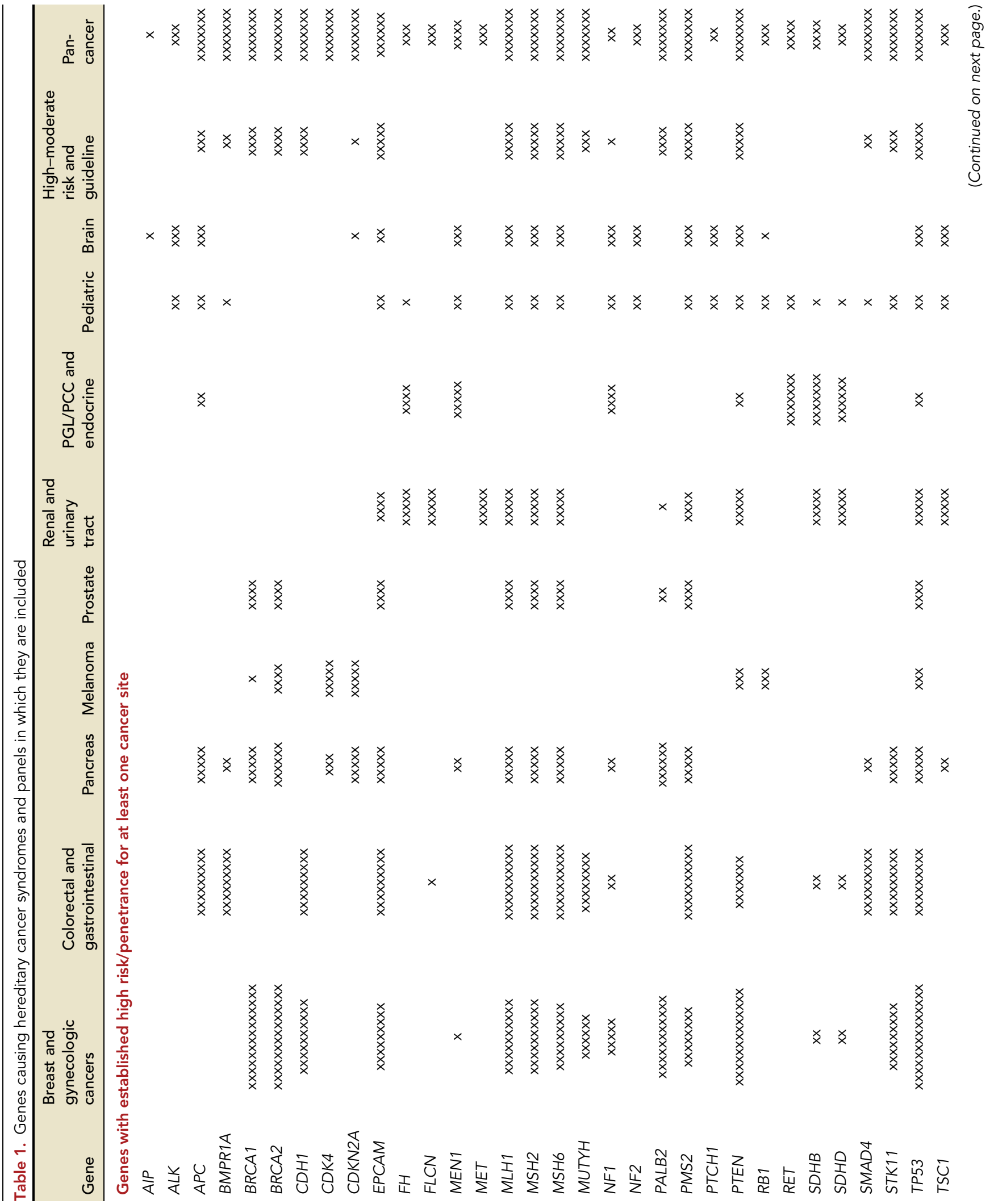




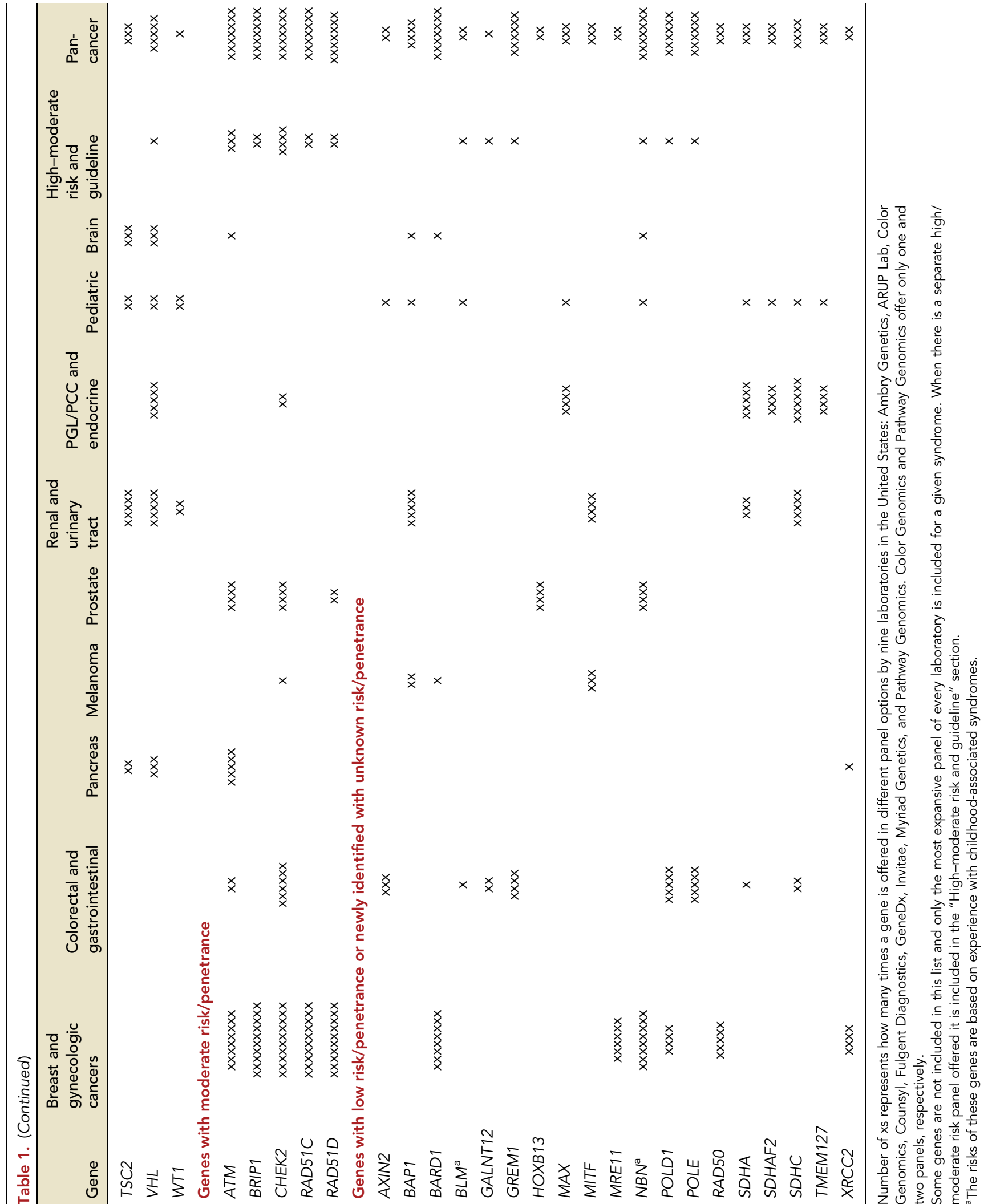


Downloaded from molecularcasestudies.cshlp.org on April 26, 2023 - Published by Cold Spring Harbor Laboratory Press

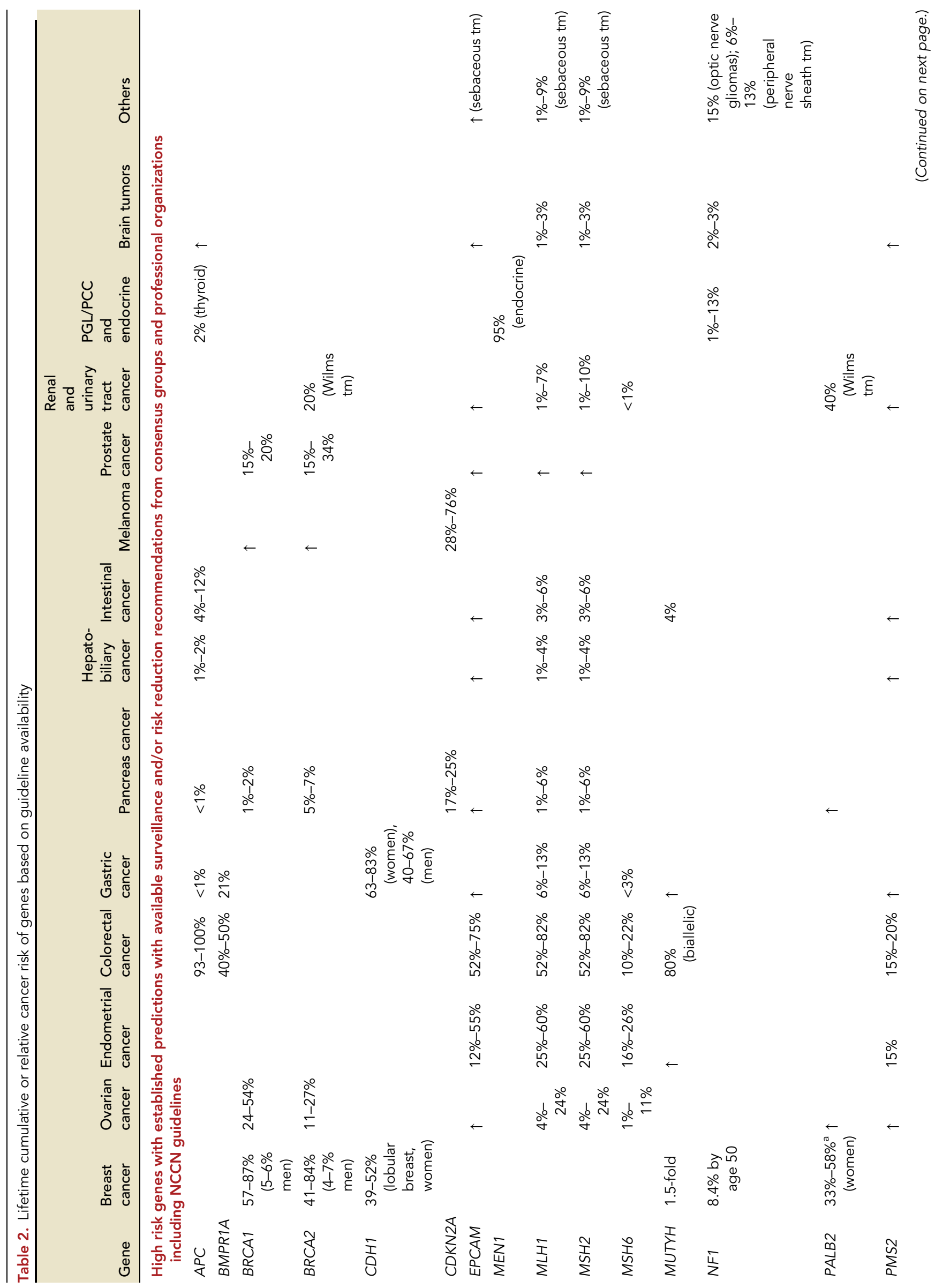


Downloaded from molecularcasestudies.cshlp.org on April 26, 2023 - Published by Cold Spring Harbor Laboratory Press

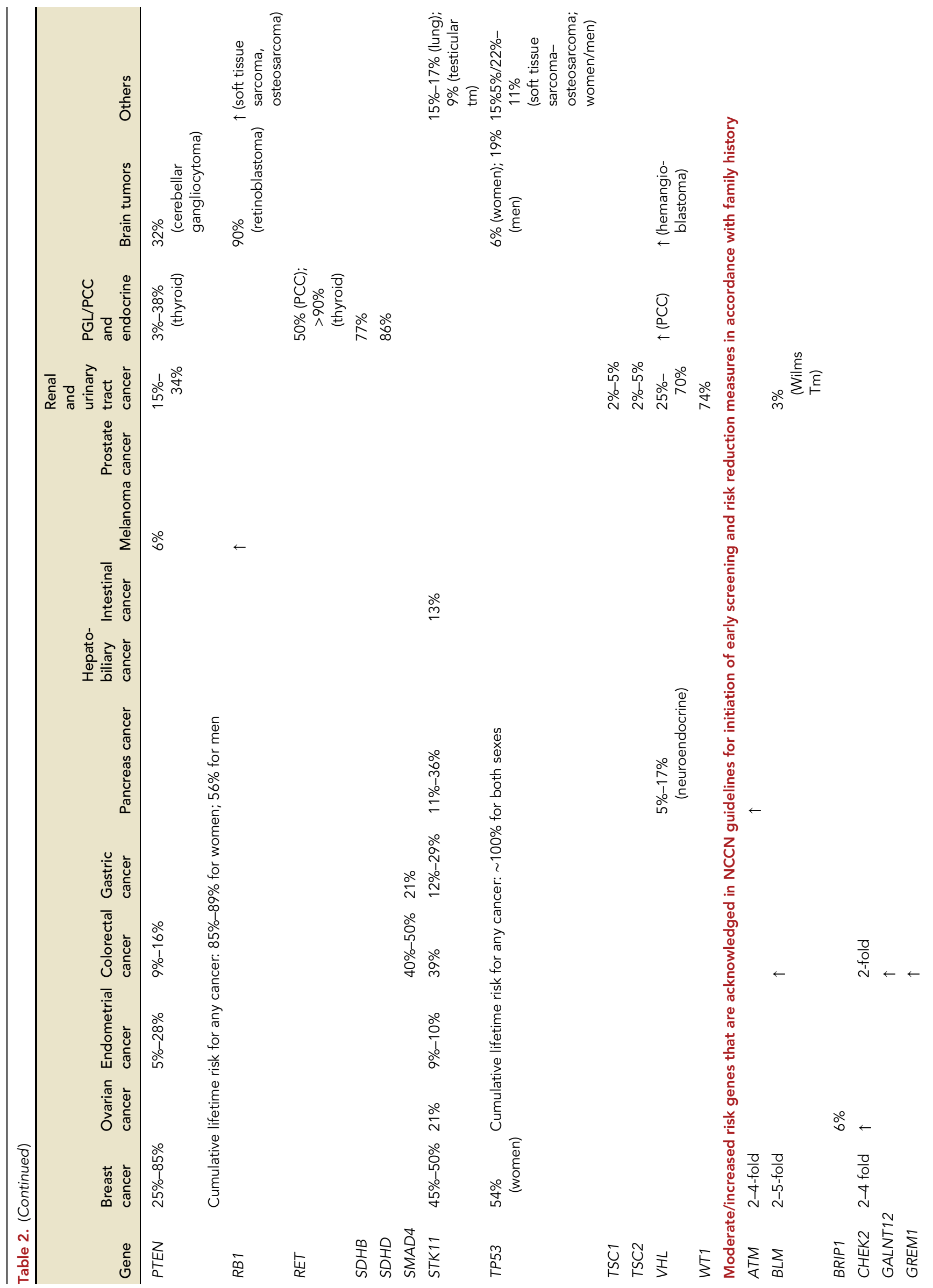




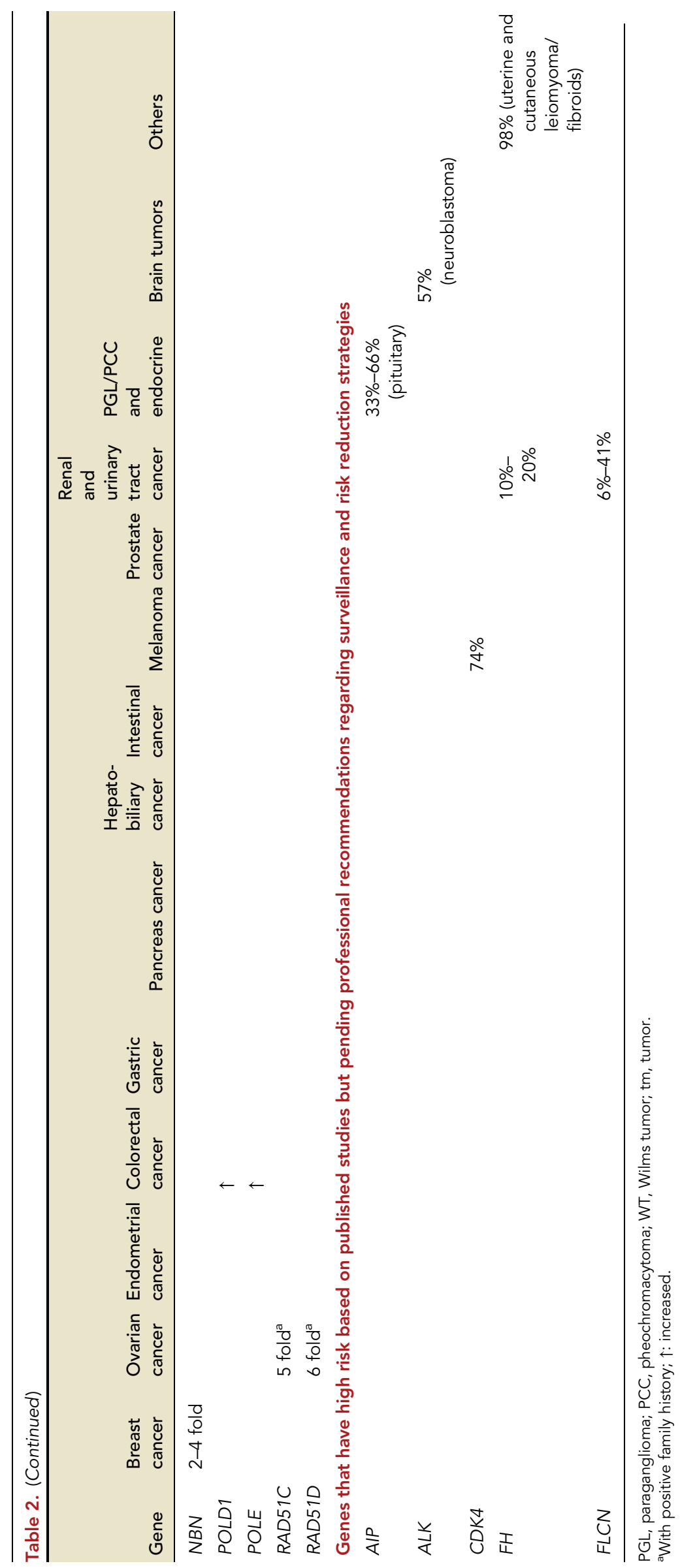


become apparent that there is a bias of ascertainment in the early literature in that research studies tended to include patients with the most significant family histories. According to one recent multigene panel study, mutations found in $>40 \%$ of patients $(n=32 / 74)$ would not have been considered for testing based on personal cancer and family history information before the introduction of panel testing strategy (Ricker et al. 2016).

With the availability of larger and larger panels, a key question has been deciding which panel to use for which patient. Many patients who received negative BRCA1/2 results many years ago before gene panels were available are returning to update their genetic testing to include more genes to guide management for themselves and their families. This strategy can exclusively be beneficial for patients, for example, with early age of onset $(<50 \mathrm{yr}$ of age), bilateral breast cancer, multiple types of cancer, and/or strong family history of breast and/or other cancers. Insurance companies have generally been covering such updates from testing performed many years ago, often because the patient's insurance carrier has changed in the interim. However, insurance companies are not always covering expansion of testing from a small panel of genes to a larger panel of genes if the former does not provide an answer if performed within a short period of time by the same carrier, and laboratories may not have a mechanism to bill if all the billable CPT codes were used at the time of the original small panel testing. For that reason, some providers are ordering larger panels initially because of concerns that subsequent testing will not be covered by insurance.

The increased demand for genetic testing has led some insurers to require a session with genetics professional before authorization of genetic testing (Hooker et al. 2017). There are significant challenges to genetic education/counseling when the number of genes tested increases from one to two genes to dozens of genes. The education/counseling has, out of necessity, become much more general in terms of the clinical utility of genetic testing rather than education/counseling about specific genes such as BRCA1/2. Because it is impossible to educate patients about all possible manifestations in all of the genes identified, tiered and binned genetic counseling models have been developed (Bradbury et al. 2015).

These genetic education/counseling sessions tend not to focus on rare circumstances in which patients are found to have mutations in genes with impact across a broad range of cancers and across the life span including children (TP53) or on genes associated not only with cancer but also autism and neurocognitive and behavioral issues (PTEN) (Goffin et al. 2001; Orrico et al. 2009).

With more expansive testing, we have begun to recognize that de novo mutations may rarely be observed in early-onset cancers, especially in children (Oberg et al. 2016), likely because of effects on reproductive fitness. Hereditary genetic testing was previously not routinely performed in children, but it is now recognized that $10 \%$ of cancers in children are due to germline mutations in some of the same genes encountered in adult cancers (BRCA1, BRCA2, PALPB2, CHEK2, TP53, MSH2, VHL) and also in genes specific to children such as DICER1, WT1, REST, CREBBP, ABCB11, GPC3/4 (Zhang et al. 2015; Parsons et al. 2016; Scollon et al. 2017). Rarely were biallelic mutations identified in autosomal recessively inherited conditions. In many instances, the type of cancer and family history were not strongly suggestive of the hereditary cancer syndrome (Parsons et al. 2016). Most of the cancer predispositions in children are inherited, and identification of these genes in children also helps to identify other family members at risk (Mody et al. 2017). Panels are now available for pediatric cancers specifically (Table 1).

In addition to the cancer implications of many of the genes on panels, some of the genes also have reproductive implications for autosomal recessive pediatric conditions such as ataxia telangiectasia or Bloom syndrome (Table 3). 
Table 3. Hereditary cancer genes that are also associated with pediatric age onset syndromes

\begin{tabular}{|c|c|c|}
\hline Gene & $\begin{array}{l}\text { Pediatric condition/inheritance } \\
\text { (\#OMIM) }\end{array}$ & $\begin{array}{l}\text { Clinical features in addition to cancer } \\
\text { predisposition }^{\text {a }}\end{array}$ \\
\hline ATM & Ataxia telangiectasia/AR (\#208900) & $\begin{array}{l}\text { Progressive cerebellar ataxia beginning between } \\
\text { ages } 1 \text { and } 4 \text { years, oculomotor apraxia, } \\
\text { choreoathetosis, telangiectasias of the } \\
\text { conjunctivae, immunodeficiency, frequent } \\
\text { infections }\end{array}$ \\
\hline BRCA2 & Fanconi anemia-D1/AR (\#605724) & Progressive bone marrow failure, short stature, \\
\hline PALB2 & Fanconi anemia-N/AR (\#610832) & abnormal skin pigmentation, skeletal \\
\hline RAD51C & Fanconi anemia-O/AR (\#613390) & $\begin{array}{l}\text { malformations of the upper and lower limbs, } \\
\text { microcephaly, and ophthalmic and genitourinary } \\
\text { tract anomalies }\end{array}$ \\
\hline$B L M$ & Bloom syndrome/AR (\#210900) & $\begin{array}{l}\text { Severe pre- and postnatal growth deficiency, } \\
\text { sparseness of subcutaneous fat tissue } \\
\text { throughout infancy and early childhood, and } \\
\text { short stature throughout postnatal life that in } \\
\text { most affected individuals is accompanied by an } \\
\text { erythematous and sun-sensitive skin lesion of the } \\
\text { face. }\end{array}$ \\
\hline $\begin{array}{l}\text { BMPR1A } \\
\text { SMAD4 }\end{array}$ & $\begin{array}{l}\text { Hereditary hemorrhagic } \\
\text { telangiectasia/AR (\#175050) }\end{array}$ & $\begin{array}{l}\text { Epistaxis, telangiectasias, (pulmonary) } \\
\text { arteriovenous malformations, and digital } \\
\text { clubbing }\end{array}$ \\
\hline $\mathrm{FH}$ & $\begin{array}{l}\text { Fumarate hydratase deficiency/AR } \\
\text { (\#606812) }\end{array}$ & $\begin{array}{l}\text { Severe neonatal and early infantile } \\
\text { encephalopathy, dysmorphic features, } \\
\text { microcephaly, cerebral atrophy, corpus callosum } \\
\text { agenesis/hypoplasia, hydrocephaly }\end{array}$ \\
\hline NBN & $\begin{array}{l}\text { Nijmegen breakage syndrome/AR } \\
\text { (\#251260) }\end{array}$ & $\begin{array}{l}\text { Progressive microcephaly, intrauterine growth } \\
\text { retardation and short stature, recurrent } \\
\text { sinopulmonary infections }\end{array}$ \\
\hline PTCH1 & Gorlin syndrome /AD (\#109400) & $\begin{array}{l}\text { Macrocephaly, frontal bossing, coarse facial } \\
\text { features, facial milia, skeletal anomalies (e.g., } \\
\text { bifid ribs, wedge-shaped vertebrae), ectopic } \\
\text { calcification (falx) }\end{array}$ \\
\hline PTEN & $\begin{array}{l}\text { Cowden syndrome (\#158350), } \\
\text { Bannayan-Riley-Ruvalcaba syndrome } \\
\text { (\#153480), macrocephaly/autism } \\
\text { syndrome (\#605309)/AD }\end{array}$ & $\begin{array}{l}\text { Macrocephaly, trichilemmomas, and papillomatous } \\
\text { papules, pigmented macules of the glans penis, } \\
\text { autism }\end{array}$ \\
\hline TSC1/2 & $\begin{array}{l}\text { Tuberous sclerosis complex/AD } \\
(\# 191100, \# 613254)\end{array}$ & $\begin{array}{l}\text { Abnormalities of the skin (hypomelanotic macules, } \\
\text { facial angiofibromas, shagreen patches, cephalic } \\
\text { plaques, ungual fibromas); brain (cortical } \\
\text { dysplasias, subependymal nodules and } \\
\text { subependymal giant cell astrocytomas [SEGAs], } \\
\text { seizures, intellectual disability/developmental } \\
\text { delay, psychiatric illness); kidney } \\
\text { (angiomyolipomas, cysts); heart (rhabdomyomas, } \\
\text { arrhythmias); and lungs } \\
\text { (lymphangioleiomyomatosis [LAM]). }\end{array}$ \\
\hline
\end{tabular}

${ }^{\mathrm{a}}$ Disease characteristics are obtained from GeneReviews entries. 


\section{CHALLENGES OF PANEL TESTING AND BEYOND}

Although we can inexpensively generate large amounts of sequence data, our ability to accurately interpret much of this information, particularly for missense variants, is still limited, leading to a significant increase in the numbers of variants of unknown significance (VUSs) as the sizes of the panels increase (Susswein et al. 2016).

The increased frequency of VUSs with the increasing number of genes evaluated is the major disadvantage to ordering excessively large gene panels. As many as $44 \%$ of patients will receive one or more VUS depending on the primary cancer site and the test ordered (Lynce and Isaacs 2016). Although many laboratories are centrally depositing data in ClinVar to facilitate data sharing and resolution of uncertain results, not all laboratories performing cancer genetic testing are depositing their data. Insurance companies have in some cases applied pressure to improve data sharing and will only reimburse for testing performed at laboratories that deposit data in ClinVar. With increasing availability of large amounts of sequence from population-based cohorts of increased ethnic diversity (ExAC and gnomAD) and with high-throughput functional assays (Millot et al. 2012; Guidugli et al. 2014; Gasperini et al. 2016), it should be possible to interpret an increasing number of VUSs, and it will be critical for such reinterpreted data to be returned to clinicians and patients as it is available to guide management. Updated interpretations will be particularly important for minority patients who have a disproportionately higher frequency of VUSs (Minion et al. 2015; Ricker et al. 2016; Susswein et al. 2016) and a lower genomic literacy to understand the nuances of a VUS (Lumish et al. 2017).

VUSs are particularly challenging for hereditary cancer predisposition syndromes because there is no independent clinical method to evaluate the pathogenicity of a variant. VUS results were found to escalate the intention to increase cancer screening practices in patients with personal cancer history or only positive family history even though patients should be counseled to follow personal and/or family history-based guidelines in the absence of an identified mutation (Lumish et al. 2017).

The major benefit of screening individuals for hereditary cancer predisposition comes from effective medical/surgical management and preventive measures (Kurian et al. 2010). We still do not have clinical surveillance and management guidelines for many of the relatively new, moderate- or low-penetrance risk genes (Table 2). For moderately penetrant genes such as ATM, which is associated with a twofold increased risk of breast cancer (Thompson et al. 2005; Renwick et al. 2006), surveillance and management recommendations will often not change if there is a personal or family history of breast cancer. For classically highly penetrant genes such as $C D H 1$ and TP53, it is unclear if the penetrance for mutation carriers who do not have a personal or family history of cancer is similar.

To address the questions of penetrance, cancer spectrum, and recommended clinical management, we need more data to enable better genotype-phenotype correlations, to estimate age- and gender-specific penetrance and expressivity, and to identify modifiable risk factors through increased data sharing. Some public registries such as ENIGMA (https ://enigmaconsortium.org) and PROMPT (http://promptstudy.org) support these studies, but the amount of data in these registries is a small fraction of the number of mutation carriers being identified clinically. It would be much more efficient and effective if patients were given the option of contributing de-identified clinical data to researchers to generate knowledge-based recommendations that will one day directly benefit the care for themselves and their families.

Some genes such as APC, VHL, and TP53 have relatively high de novo mutation rates (Hes et al. 2008; Prochazkova et al. 2009; Wu et al. 2012, 2013), and family history is not contributory in those cases and makes these diagnoses more unexpected for the patient and 
COLD SPRING HARBOR Molecular Case Studies
The impact of hereditary cancer gene panels clinician. Additionally, TP53 mutations are not uncommonly detected as somatic mutations in blood and may be incidental but must be differentiated from germline mutations by performing a skin biopsy (Pospisilova et al. 2012; Slavin et al. 2015).

Analysis of some genes such as PMS2 is particularly complicated because of highly homologous pseudogenes (van der Klift et al. 2016). These regions are difficult to uniquely map with short-read NGS-based panels; therefore, some clinically significant variants in those regions may not be easily detected, and sensitivity for mutations in these genes can differ by the methods beyond the short-read NGS used by the laboratory to interrogate these regions.

In recent years, matched tumor-germline and tumor-only sequencing studies identify actionable germline mutations that can guide the therapeutic management of the cancer (e.g., BRCA1/BRCA2 mutations and Olaparib) (Hennessy et al. 2010; Ledermann et al. 2014; Kurian et al. 2017) and prevention of future associated cancer. With tumor sequencing, $5 \%-15 \%$ of patients unselected for family history are found to harbor pathogenic or likely pathogenic variants in hereditary cancer predisposition genes (Schrader et al. 2016; Seifert et al. 2016). Although this type of testing is beneficial, many patients are not receiving any genetic education or genetic counseling and may be surprised when germline results are returned. As more tumor sequence is publicly available in the Catalogue of Somatic Mutations in Cancer (COSMIC; http://cancer.sanger.ac.uk/cosmic), The Cancer Genome Atlas (TCGA; https://cancergenome.nih.gov/), and the International Cancer Genome Consortium (http://icgc.org/), annotations of germline variants will be helpful with variant interpretation.

With the increased demand for cancer panel gene testing, there is an increased need for genetic education and genetic counseling and an inadequate number of genetic professionals to provide these services. There is a need to train additional genetic counselors, to train other providers to provide care in genomic medicine, and to develop education tools including easily understandable and culturally appropriate educational videos to enable the provision of appropriate care to patients on scale.

\section{DETERMINANTS OF TEST SELECTION}

Choosing the right panel depends on multiple factors (Fig. 1). Family history is important, but can be limited by small family size or gender distribution, early deaths due to nonmedical causes, or lack of information about family members' medical issues. The high population prevalence of cancer in older individuals may also obscure the pattern of cancers attributable to genetic factors versus other environmental causes and make selection of the right panel more difficult.

Cost and coverage for testing are important factors. BRCA1/2 is the one genetic test covered under the Affordable Care Act. Many insurance companies, Medicaid, and Medicare have guidelines for genetic testing for common cancers. The cost of testing has come down as low as $\$ 250$, enabling some patients to pay out-of-pocket for testing even when not covered by insurance.

Laboratories differ slightly in their gene composition, techniques for detecting insertions/deletions/rearrangements, variant interpretation approaches, variant reinterpretation policies, reference database, and what they include in their test reports and how they present the information. Most of the high-volume cancer genetic laboratories offer options for panels of various sizes and composition to tailor to the needs of patients by cancer type. Some laboratories also offer a la carte options to select specific genes of interest for the patient.

As the cost of sequencing continues to drop, WES has been considered as an alternative to panels. Targeted gene panels have some advantages over WES in terms of average mean 


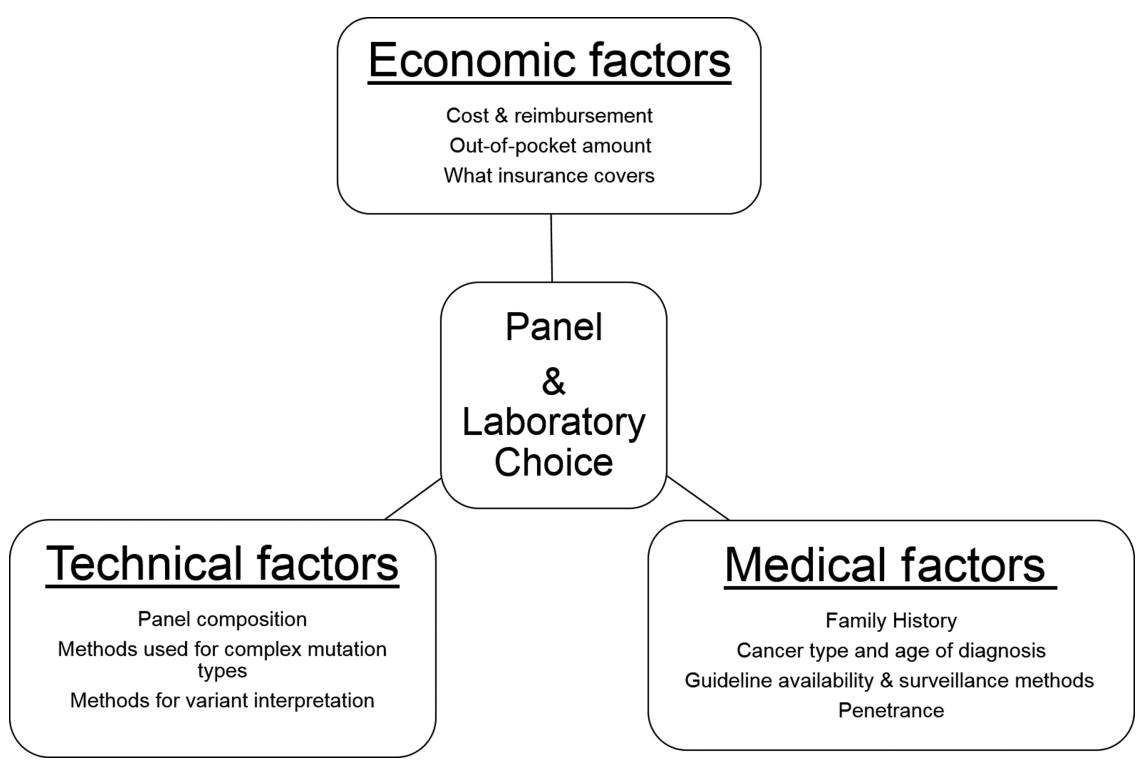

Figure 1. Factors affecting the panel and laboratory choice.

read depth and coverage of genes of interest (Feliubadaló et al. 2017). Turnaround time is shorter with targeted gene panels because the amount of data to analyze is considerably less. WES can be considered for patients with multiple primaries at young ages, and/or a strong family history of site-specific cancer with normal genetic test results from a large panel on at least one affected individual. There are certainly likely to be novel hereditary cancer genes to be discovered; however, given the large size of largest panels, results from WES are likely to identify novel genes that will necessarily be of uncertain significance until more data is gathered on these genes. Increasingly, genomic sequencing data will be available on paired tumor/normal tissue samples that may help to identify some of these novel genes.

\section{WHAT WILL THE FUTURE HOLD?}

Given the relatively widespread adoption of panel gene testing to date and the clear value in making molecular diagnoses that otherwise would have been missed by routine clinical guidelines, we suggest that panel gene testing will continue to be the norm in hereditary cancer testing. As data are available to better interpret variants, as systems are put in place to deal with reinterpretation of VUSs, and as providers become educated about how to manage patients with VUSs, the concern about receipt of VUSs will be less of a deterrent to large panels. The field will likely shift to offering germline genetic testing to all patients with breast, ovarian, uterine, colon, stomach, pancreas, prostate, and renal cancers, pheochromocytomas, and sarcomas for a panel of genes associated with high risk and with NCCN guidelines for these cancers. Germline testing will increasingly be done in parallel with tumor testing for a panel of genes/mutations that are actionable for treatment. Beyond this "basic panel" of high-risk genes with NCCN guideline, expanded panels including newer genes of uncertain penetrance and moderate/low risk genes will be incorporated with polygenic risk scores derived from approximately 100 common polymorphisms to provide more accurate and comprehensive risk stratification. An alternative option will be exome/genome sequencing as the cost of sequencing comes down with the new NovaSeq sequencers and as interpretation systems are developed to efficiently analyze thousands of variants simultaneously. 
Competing Interest Statement

The authors have declared no competing interest.
Population-based screening of unaffected individuals is also likely to gain traction with the introduction of less expensive cancer panel testing, especially if it can be proven to be cost-effective in the general population (Gabai-Kapara et al. 2014; Long and Ganz 2015).

As we move forward with advances in genomic medicine, we are building the plane as we are flying it. To enable advances to be made as quickly as possible for the patients who can benefit from genomic advances, we need to embrace sharing and distribution of de-identified clinical and genetic data collected in the process of routine clinical care, strongly protect the privacy of patients' data, and commit to returning the new knowledge we acquire to patients who need and deserve the information.

\section{REFERENCES}

Berry DA, Iversen ES Jr, Gudbjartsson DF, Hiller EH, Garber JE, Peshkin BN, Lerman C, Watson P, Lynch HT, Hilsenbeck SG, et al. 2002. BRCAPRO validation, sensitivity of genetic testing of BRCA1/BRCA2, and prevalence of other breast cancer susceptibility genes. J Clin Oncol 20: 2701-2712.

Blazer KR, Nehoray B, Solomon I, Niell-Swiller M, Culver JO, Uman GC, Weitzel JN. 2015. Next-generation testing for cancer risk: perceptions, experiences, and needs among early adopters in community healthcare settings. Genet Test Mol Biomarkers 19: 657-665.

Borzekowski DL, Guan Y, Smith KC, Erby LH, Roter DL. 2014. The Angelina effect: immediate reach, grasp, and impact of going public. Genet Med 16: 516-521.

Bradbury AR, Patrick-Miller L, Long J, Powers J, Stopfer J, Forman A, Rybak C, Mattie K, Brandt A, Chambers R, et al. 2015. Development of a tiered and binned genetic counseling model for informed consent in the era of multiplex testing for cancer susceptibility. Genet Med 17: 485-492.

Drohan B, Roche CA, Cusack JC Jr, Hughes KS. 2012. Hereditary breast and ovarian cancer and other hereditary syndromes: using technology to identify carriers. Ann Surg Oncol 19: 1732-1737.

Feliubadaló L, Tonda R, Gausachs M, Trotta JR, Castellanos E, Lopez-Doriga A, Teulé A, Tornero E, Del Valle J, Gel B, et al. 2017. Benchmarking of whole exome sequencing and ad hoc designed panels for genetic testing of hereditary cancer. Sci Rep 7: 37984.

Gabai-Kapara E, Lahad A, Kaufman B, Friedman E, Segev S, Renbaum P, Beeri R, Gal M, Grinshpun-Cohen J, Djemal K, et al. 2014. Population-based screening for breast and ovarian cancer risk due to BRCA1 and BRCA2. Proc Natl Acad Sci 111: 14205-14210.

Gasperini M, Starita L, Shendure J. 2016. The power of multiplexed functional analysis of genetic variants. Nat Protoc 11: 1782-1787.

Goffin A, Hoefsloot LH, Bosgoed E, Swillen A, Fryns JP. 2001. PTEN mutation in a family with Cowden syndrome and autism. Am J Med Genet 105: 521-524.

Guidugli L, Carreira A, Caputo SM, Ehlen A, Galli A, Monteiro AN, Neuhausen SL, Hansen TV, Couch FJ, Vreeswijk MP. 2014. Functional assays for analysis of variants of uncertain significance in BRCA2. Hum Mutat 35: 151-164.

Hampel H, Bennett RL, Buchanan A, Pearlman R, Wiesner GL; Guideline Development Group, American College of Medical Genetics and Genomics Professional Practice and Guidelines Committee and National Society of Genetic Counselors Practice Guidelines Committee. 2015. A practice guideline from the American College of Medical Genetics and Genomics and the National Society of Genetic Counselors: referral indications for cancer predisposition assessment. Genet Med 17: 70-87.

Hennessy BT, Timms KM, Carey MS, Gutin A, Meyer LA, Flake DD II, Abkevich V, Potter J, Pruss D, Glenn P, et al. 2010. Somatic mutations in BRCA1 and BRCA2 could expand the number of patients that benefit from poly(ADP ribose) polymerase inhibitors in ovarian cancer. J Clin Oncol 28: 3570-3576.

Hes FJ, Nielsen M, Bik EC, Konvalinka D, Wijnen JT, Bakker E, Vasen HF, Breuning MH, Tops CM. 2008. Somatic APC mosaicism: an underestimated cause of polyposis coli. Gut 57: 71-76.

Hooker GW, Clemens KR, Quillin J, Vogel Postula KJ, Summerour P, Nagy R, Buchanan AH. 2017. Cancer genetic counseling and testing in an era of rapid change. J Genet Couns doi: 10.1007/s10897-017-0099-2.

Kamenova K, Reshef A, Caulfield T. 2014. Angelina Jolie's faulty gene: newspaper coverage of a celebrity's preventive bilateral mastectomy in Canada, the United States, and the United Kingdom. Genet Med 16: 522-528.

Kapoor NS, Curcio LD, Blakemore CA, Bremner AK, McFarland RE, West JG, Banks KC. 2015. Multigene panel testing detects equal rates of pathogenic BRCA1/2 mutations and has a higher diagnostic yield compared to limited BRCA1/2 analysis alone in patients at risk for hereditary breast cancer. Ann Surg Oncol 22: $3282-3288$ 
Kosenko KA, Binder AR, Hurley R. 2016. Celebrity influence and identification: a test of the Angelina effect. $J$ Health Commun 21: 318-326.

Kurian AW, Sigal BM, Plevritis SK. 2010. Survival analysis of cancer risk reduction strategies for BRCA1/2 mutation carriers. J Clin Oncol 28: 222-231.

Kurian AW, Li Y, Hamilton AS, Ward KC, Hawley ST, Morrow M, McLeod MC, Jagsi R, Katz SJ. 2017. Gaps in incorporating germline genetic testing into treatment decision-making for early-stage breast cancer. J Clin Oncol 35: 2232-2239.

Ledermann J, Harter P, Gourley C, Friedlander M, Vergote I, Rustin G, Scott CL, Meier W, Shapira-Frommer R, Safra T, et al. 2014. Olaparib maintenance therapy in patients with platinum-sensitive relapsed serous ovarian cancer: a preplanned retrospective analysis of outcomes by BRCA status in a randomised phase 2 trial. Lancet Oncol 15: 852-861.

Long EF, Ganz PA. 2015. Cost-effectiveness of universal BRCA1/2 screening: evidence-based decision making. JAMA Oncol 1: 1217-1218.

Lu KH, Wood ME, Daniels M, Burke C, Ford J, Kauff ND, Kohlmann W, Lindor NM, Mulvey TM, Robinson L, et al. 2014. American Society of Clinical Oncology Expert Statement: collection and use of a cancer family history for oncology providers. J Clin Oncol 32: 833-840.

Lumish HS, Steinfeld H, Koval C, Russo D, Levinson E, Wynn J, Duong J, Chung WK. 2017. Impact of panel gene testing for hereditary breast and ovarian cancer on patients. J Genet Couns doi: 10.1007/s10897017-0090-y.

Lynce F, Isaacs C. 2016. How far do we go with genetic evaluation? Gene, panel, and tumor testing. Am Soc Clin Oncol Educ Book 35: e72-e78.

Millot GA, Carvalho MA, Caputo SM, Vreeswijk MP, Brown MA, Webb M, Rouleau E, Neuhausen SL, Hansen T, Galli A, et al. 2012. A guide for functional analysis of BRCA1 variants of uncertain significance. Hum Mutat 33: 1526-1537.

Minion LE, Dolinsky JS, Chase DM, Dunlop CL, Chao EC, Monk BJ. 2015. Hereditary predisposition to ovarian cancer, looking beyond BRCA1/BRCA2. Gynecol Oncol 137: 86-92.

Mody RJ, Prensner JR, Everett J, Parsons DW, Chinnaiyan AM. 2017. Precision medicine in pediatric oncology: lessons learned and next steps. Pediatr Blood Cancer 64. doi: 10.1002/pbc.26288.

Oberg JA, Glade Bender JL, Sulis ML, Pendrick D, Sireci AN, Hsiao SJ, Turk AT, Dela Cruz FS, Hibshoosh H, Remotti $\mathrm{H}$, et al. 2016. Implementation of next generation sequencing into pediatric hematology-oncology practice: moving beyond actionable alterations. Genome Med 8: 133.

Orrico A, Galli L, Buoni S, Orsi A, Vonella G, Sorrentino V. 2009. Novel PTEN mutations in neurodevelopmental disorders and macrocephaly. Clin Genet 75: 195-198.

Parmigiani G, Berry D, Aguilar O. 1998. Determining carrier probabilities for breast cancer-susceptibility genes BRCA1 and BRCA2 Am J Hum Genet 62: 145-158.

Parsons DW, Roy A, Yang Y, Wang T, Scollon S, Bergstrom K, Kerstein RA, Gutierrez S, Petersen AK, Bavle A, et al. 2016. Diagnostic yield of clinical tumor and germline whole-exome sequencing for children with solid tumors. JAMA Oncol doi: 10.1001/jamaoncol.2015.5699.

Pennington KP, Walsh T, Harrell MI, Lee MK, Pennil CC, Rendi MH, Thornton A, Norquist BM, Casadei S, Nord AS, et al. 2014. Germline and somatic mutations in homologous recombination genes predict platinum response and survival in ovarian, fallopian tube, and peritoneal carcinomas. Clin Cancer Res 20: 764-775.

Pospisilova S, Gonzalez D, Malcikova J, Trbusek M, Rossi D, Kater AP, Cymbalista F, Eichhorst B, Hallek M, Dohner $\mathrm{H}$, et al. 2012. ERIC recommendations on TP53 mutation analysis in chronic lymphocytic leukemia. Leukemia 26: 1458-1461.

Prochazkova K, Pavlikova K, Minarik M, Sumerauer D, Kodet R, Sedlacek Z. 2009. Somatic TP53 mutation mosaicism in a patient with Li-Fraumeni syndrome. Am J Med GenetA 149a: 206-211.

Renwick A, Thompson D, Seal S, Kelly P, Chagtai T, Ahmed M, North B, Jayatilake H, Barfoot R, Spanova K, et al. 2006. ATM mutations that cause ataxia-telangiectasia are breast cancer susceptibility alleles. Nat Genet 38: 873-875.

Ricker C, Culver JO, Lowstuter K, Sturgeon D, Sturgeon JD, Chanock CR, Gauderman WJ, McDonnell KJ, Idos GE, Gruber SB. 2016. Increased yield of actionable mutations using multi-gene panels to assess hereditary cancer susceptibility in an ethnically diverse clinical cohort. Cancer Genet 209: 130-137.

Robson ME, Bradbury AR, Arun B, Domchek SM, Ford JM, Hampel HL, Lipkin SM, Syngal S, Wollins DS, Lindor NM. 2015. American Society of Clinical Oncology policy statement update: genetic and genomic testing for cancer susceptibility. J Clin Oncol 33: 3660-3667.

Rodriguez-Bigas MA, Boland CR, Hamilton SR, Henson DE, Jass JR, Khan PM, Lynch H, Perucho M, Smyrk T, Sobin L, et al. 1997. A National Cancer Institute Workshop on Hereditary Nonpolyposis Colorectal Cancer Syndrome: meeting highlights and Bethesda guidelines. J Natl Cancer Inst 89: 1758-1762.

Schrader KA, Cheng DT, Joseph V, Prasad M, Walsh M, Zehir A, Ni A, Thomas T, Benayed R, Ashraf A, et al. 2016. Germline variants in targeted tumor sequencing using matched normal DNA. JAMA Oncol 2 104-111. 
COLD SPRING HARBOR Molecular Case Studies
The impact of hereditary cancer gene panels

Scollon S, Anglin AK, Thomas M, Turner JT, Wolfe Schneider K. 2017. A comprehensive review of pediatric tumors and associated cancer predisposition syndromes. J Genet Couns 26: 387-434.

Seifert BA, O'Daniel JM, Amin K, Marchuk DS, Patel NM, Parker JS, Hoyle AP, Mose LE, Marron A, Hayward MC, et al. 2016. Germline analysis from tumor-germline sequencing dyads to identify clinically actionable secondary findings. Clin Cancer Res 22: 4087-4094.

Slavin TP, Niell-Swiller M, Solomon I, Nehoray B, Rybak C, Blazer KR, Weitzel JN. 2015. Clinical application of multigene panels: challenges of next-generation counseling and cancer risk management. Front Oncol 5: 208.

Susswein LR, Marshall ML, Nusbaum R, Vogel Postula KJ, Weissman SM, Yackowski L, Vaccari EM, Bissonnette J, Booker JK, Cremona ML, et al. 2016. Pathogenic and likely pathogenic variant prevalence among the first 10,000 patients referred for next-generation cancer panel testing. Genet Med 18: 823-832.

Thompson D, Duedal S, Kirner J, McGuffog L, Last J, Reiman A, Byrd P, Taylor M, Easton DF. 2005. Cancer risks and mortality in heterozygous ATM mutation carriers. J Natl Cancer Inst 97: 813-822.

Umar A, Boland CR, Terdiman JP, Syngal S, de la Chapelle A, Ruschoff J, Fishel R, Lindor NM, Burgart LJ, Hamelin R, et al. 2004. Revised Bethesda Guidelines for hereditary nonpolyposis colorectal cancer (Lynch syndrome) and microsatellite instability. J Natl Cancer Inst 96: 261-268.

van der Klift HM, Mensenkamp AR, Drost M, Bik EC, Vos YJ, Gille HJJP, Redeker BEJW, Tiersma Y, Zonneveld JBM, García EG, et al. 2016. Comprehensive mutation analysis of PMS2 in a large cohort of probands suspected of Lynch syndrome or constitutional mismatch repair deficiency syndrome. Hum Mutat 37: 1162-1179.

Vasen HF, Mecklin JP, Khan PM, Lynch HT. 1991. The international collaborative group on hereditary non-polyposis colorectal cancer (ICG-HNPCC). Dis Colon Rectum 34: 424-425.

Wu P, Zhang N, Wang X, Ning X, Li T, Bu D, Gong K. 2012. Family history of von Hippel-Lindau disease was uncommon in Chinese patients: suggesting the higher frequency of de novo mutations in VHL gene in these patients. J Hum Genet 57: 238-243.

Wu P, Zhang N, Wang X, Li T, Ning X, Bu D, Gong K. 2013. Mosaicism in von Hippel-Lindau disease with severe renal manifestations. Clin Genet 84: 581-584.

Zhang J, Walsh MF, Wu G, Edmonson MN, Gruber TA, Easton J, Hedges D, Ma X, Zhou X, Yergeau DA, et al. 2015. Germline mutations in predisposition genes in pediatric cancer. N Engl J Med 373: 2336-2346. 


\section{COLD SPRING HARBOR Molecular Case Studies}

\section{The impact of hereditary cancer gene panels on clinical care and lessons learned}

Volkan Okur and Wendy K. Chung

Cold Spring Harb Mol Case Stud 2017, 3: a002154

Access the most recent version at doi: $10.1101 / \mathrm{mcs} . \mathrm{a} 002154$

References This article cites 50 articles, 9 of which can be accessed free at: http://molecularcasestudies.cshlp.org/content/3/6/a002154.full.html\#ref-list-1

License This article is distributed under the terms of the Creative Commons Attribution-NonCommercial License, which permits reuse and redistribution, except for commercial purposes, provided that the original author and source are credited.

Email Alerting Receive free email alerts when new articles cite this article - sign up in the box at the Service top right corner of the article or click here. 